This is the preprint version (with color figures) of the article:

Gyöngyvér Szanyi, Zoltán Gráczer \& Erzsébet Győri:

Ambient seismic noise Rayleigh wave tomography for the Pannonian basin

The final published version of the paper appeared in black and white in:

Acta Geodaetica et Geophysica, 2013, Volume 48, Issue 2, pp. 209-220.

Publisher's version: http://dx.doi.org/10.1007/s40328-013-0019-3 


\title{
Ambient seismic noise Rayleigh wave tomography for the Pannonian basin
}

\author{
Gyöngyvér Szanyi · Zoltán Gráczer • \\ Erzsébet Györi
}

Received: 23 November 2012 / Accepted: date

\begin{abstract}
We studied the Rayleigh wave group velocities beneath Hungary using ambient seismic noise tomography. Noise data were gathered from 17 broadband seismological stations in and around the Pannonian basin. The cross-correlation method was used to calculate the Green's functions. Group velocities belonging to the fundamental mode Rayleigh waves were determined by multiple filter technique. We measured the dispersion curves for each station pair in a period range of 7-28 s and computed maps of group velocity distribution using a 2D tomography method. The group velocity maps of $7-14 \mathrm{~s}$ periods correlate well with sedimentary thickness and regional geology. Velocity anomalies observed at longer periods reflect the effect of the crustal and mantle structural features.
\end{abstract}

Keywords Pannonian basin · ambient seismic noise $\cdot$ cross-correlation · surface wave tomography

\section{Introduction}

The Pannonian basin is located in the eastern part of central Europe. It is surrounded by the Dinarides, the Eastern Alps and the Carpathian Mountains.

The basin formation started in the Early Miocene due to the Europe-Africa convergence. The extensional collapse of the Eastern Alps and the continuous push of the Adriatic microplate resulted in the extrusion of crustal blocks from

\footnotetext{
Gyöngyvér Szanyi

MTA CSFK GGI

1112 Budapest, Meredek u. 18

Tel.: +361248 2300

Fax: +36 12482301

E-mail: szanyi.gyongyver@csfk.mta.hu

Zoltán Gráczer

MTA CSFK GGI

1112 Budapest, Meredek u. 18.

Erzsébet Győri

MTA CSFK GGI

1112 Budapest, Meredek u. 18.
} 
the Alpine orogen (Royden et al, 1982; Ratschbacher et al, 1991; Horváth, 1993; Horváth and Cloetingh, 1996)

Subduction of the European foreland and associated rollback of the subducted slab caused lithospheric extension and asthenospheric updoming during the Middle Miocene while discrete basins opened up due to the extension (Royden et al, 1982; Royden and Horváth, 1988; Horváth, 1993; Bada et al, 2001; Horváth, 2007). Cooling of the asthenospheric dome led to the subsidence of the whole Pannonian basin in the Late Miocene (Horváth and Cloetingh, 1996; Horváth, 2007).

The continuous indentation and counterclockwise rotation of the Adriatic microplate eventually interrupted the subsidence and caused the inversion of the basin system, resulting in large scale folding during the latest Pliocene and Quaternary (Horváth, 1995; Horváth, 2007; Bada et al, 2007).

As a result of the extension the Pannonian basin can be characterized by shallow Moho discontinuity (Grad et al, 2009) and high surface heat flow (Lenkey, 1999; Lenkey et al, 2002).

The crustal and upper mantle $\mathrm{P}$-wave velocities and the structure of the Pannonian basin is well known from inversion of crustal phase travel times (Mónus, 1995; Gráczer and Wéber, 2012), refraction and reflection seismic surveys (Posgay et al, 1986, 1995; Guterch et al, 2000, 2003; Grad et al, 2006, 2009) and tomographic studies (Hovland et al, 1981; Babuška et al, 1984; Granet and Trampert, 1989; Spakman et al, 1993; Fan and Wallace, 1998; Mele et al, 1998; Hearn, 1999; Wéber, 2002; Piromallo and Morelli, 2003; Bus, 2004; Dando et al, 2011).

Shear wave velocity structure of the Pannonian basin was studied by the means of surface wave analysis (Calcagnile and Panza, 1990; Bondár et al, 1996), receiver function inversion (Bus, 2003, 2004; Hetényi and Bus, 2007; Hetényi et al, 2009) and teleseismic earthquake tomography (Dando et al, 2011).

Several studies have shown that surface wave tomography can be used in imaging of the crust and upper mantle on both regional (He et al, 2005; Sabra et al, 2005) and continental scale (Villaseñor et al, 2001; Yanovskaya and Kozhevnikov, 2003; Yang et al, 2007).

Ambient noise surface wave tomography has advantages compared to earthquakebased methods. It is easily applicable in territories with low seismicity, and only the station configuration defines the path coverage. Nevertheless, the observable fundamental mode Rayleigh wave period range strongly depends on the interstation distances. The closer the stations are to each other, the shorter the period of surface waves are measurable and the shallower structure can be revealed. The method has been successfully applied in local (Boaga et al, 2010), regional (Sabra et al, 2005; Shapiro et al, 2005; Villaseñor et al, 2007; Gaite et al, 2012; Kim et al, 2012; Verbeke et al, 2012) and continental studies (Yang et al, 2007; Bensen et al, 2008).

In our paper we present an ambient noise Rayleigh wave group velocity tomography for the Pannonian basin based on the data of 17 permanent seismological stations.

\section{Method}

Theoretical research and experiments (Lobkis and Weaver, 2001; Weaver and Lobkis, 2001; Shapiro and Campillo, 2004; Larose et al, 2005; Sabra et al, 2005) 


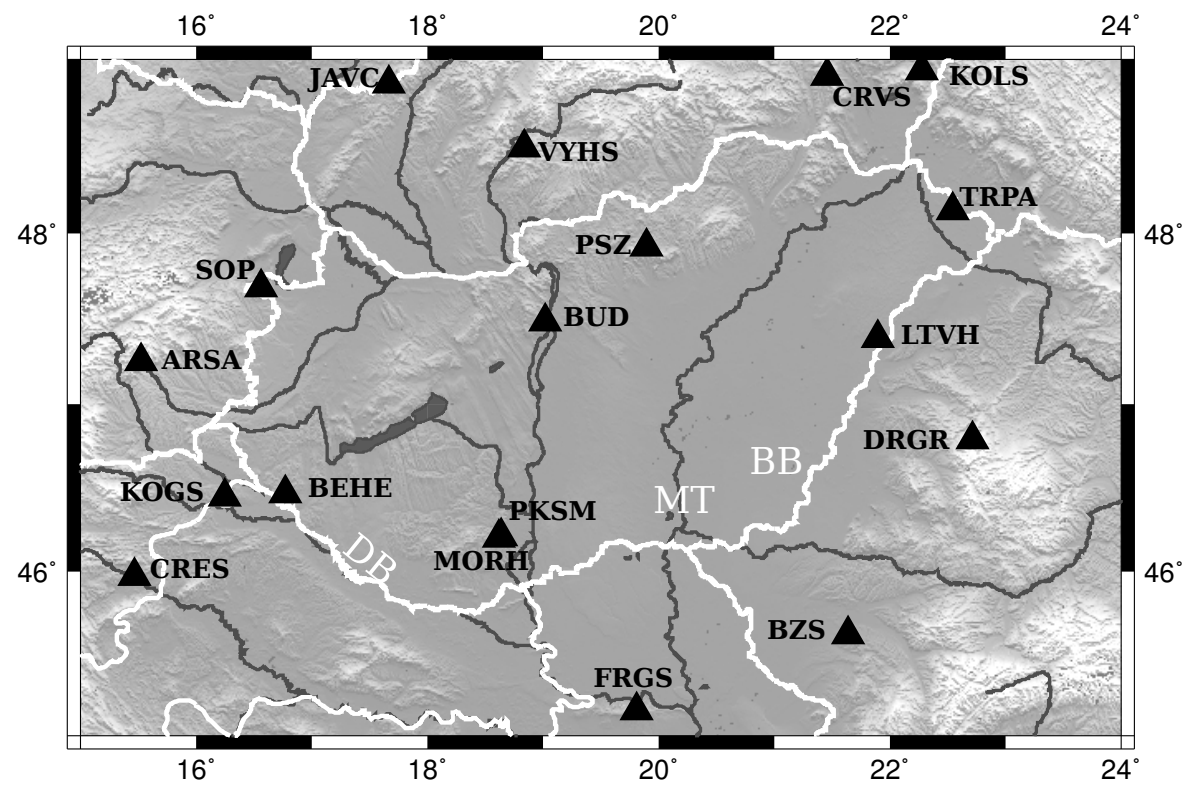

Fig. 1 Location of the stations (black triangle) whose data were used in our computations and geographical units mentioned in the paper. LHP: Little Hungarian Plain; TM: Transdanubian Mountains; TH: Transdanubian Hills; NHM: North Hungarian Mountains; GHP: Great Hungarian Plain; DB: Dráva basin; BB: Békés basin; MT: Makó trench.

have proven that an estimate of the Green's function can be obtained from crosscorrelation of long-term ambient seismic noise records. The cross-correlation functions $(\mathrm{CCF})$ can be interpreted as surface waves originated from a source at a seismic station and registered at the other. These CCFs are two-sided time functions with both positive and negative correlation lags. They are used to determine dispersion curves which in turn can be used for tomography. Cross-correlation technique works best when the noise distribution is uniform in space and time (Larose, 2004). Asymmetry in noise sources can result in asymmetric CCF, which requires further processing steps.

\subsection{Data collection}

In ambient noise tomography, raypath coverage is determined by the distribution of the stations. To get a good azimuthal coverage, records were collected from the seismological stations located in Hungary and in the surrounding countries (Fig. 1). The data were extracted from the archive of the MTA CSFK GGI Kövesligethy Radó Seismological Observatory or obtained from the GEOFON website in mseed format using the ArcLink protocol. Daily segments of vertical component LHZ stream were downloaded; if LHZ was not available, then the BHZ or the HHZ stream was acquired. Six permanent broadband stations (BEHE, BUD, PKSM, PSZ, SOP, TRPA) have been working in Hungary since 2005, and a new station (LTVH) was deployed in 2011. The broadband station PKSM was shut down in 
May 2011 and reinstalled as MORH few hundred meters from its original place, thus these two stations can be regarded as one from our point of view. Seismological station parameters, sensor types and data intervals are listed in Table 1.

\subsection{Data processing}

Our data processing method is based on that discussed by Bensen et al (2007); Yang et al (2007); Ditmar and Yanovskaya (1987) and Yanovskaya and Ditmar (1990). It consists of three main steps: 1) calculation of the Green's function from seismic noise; 2) determination of the Rayleigh wave fundamental mode group velocity dispersion curves; 3) 2D group velocity tomography.

Seismic records of BHZ and HHZ streams were resampled to $1 \mathrm{~Hz}$ prior to any further analysis. Daily seismograms shorter than 86200 s were neglected. We corrected the remaining records for instrument response and removed the mean and trend, after which data were bandpass filtered between 4 and $50 \mathrm{~s}$.

When we compute the CCFs from ambient seismic noise recordings, the earthquake signals are undesirable. Different types of normalization methods can be used to remove the influence of the earthquakes, e.g. running-absolute-mean, onebit, clipped waveform or water level normalization. According to Bensen et al (2007), running-absolute-mean normalization gives the best results. Nevertheless, one-bit normalization gives nearly as good result as the running-absolute-mean method, while the processing time is significantly less. Therefore, we used one-bit normalization for earthquake signal removal. During this process all non negative amplitudes are replaced with a value of 1 and all negative amplitudes with -1 . One-bit normalization has been successfully used in a number of seismic studies (Campillo and Paul, 2003; Shapiro and Campillo, 2004; Shapiro et al, 2005; Yao et al, 2006).

Cross-correlation functions were calculated for 1 hour segments and stacked over longer period. Calculations were performed between all possible station pairs using the seismological programs by Robert B. Herrmann (Herrmann and Ammon, 2002). The difference of the positive and negative time lags of the resulting CCFs were negligible, which means that the noise distribution can be considered uniform. Cross-correlation functions without clear Green's function were omitted and not used in further processing steps.

Dispersion curves from 7 to 28 s period were measured manually using multiple filter technique (MFT) (Dziewonski et al, 1969; Herrmann, 1973). MFT plots for every station pair were determined for the years 2008 and 2011. As part of the quality control, the plots were visually inspected and compared for close paths. As a result 118 dispersion curves were obtained from 136 CCFs.

To obtain reliable dispersion curves at period $T$, the interstation distance $(\Delta)$ must be at least 3 wavelengths $(\lambda): \Delta>3 \lambda=3 c T$ (Bensen et al, 2007). If the phase velocity is $c \sim 4 \mathrm{~km} / \mathrm{s}$, the maximum cut-off period is about $T_{\max }=\frac{\Delta}{12 \mathrm{~km} / \mathrm{s}}$ for measurements at $\Delta$ interstation spacing. In our case, the maximum distance between the stations is $609 \mathrm{~km}$, thus the theoretical cut-off period is around $50 \mathrm{~s}$. Dispersion curves were truncated based on the 3 wavelengths criterium.

The above described process gives different number of paths for each period (Fig. 2). The variable number of paths results in a period dependent coverage (Fig. $3)$. 


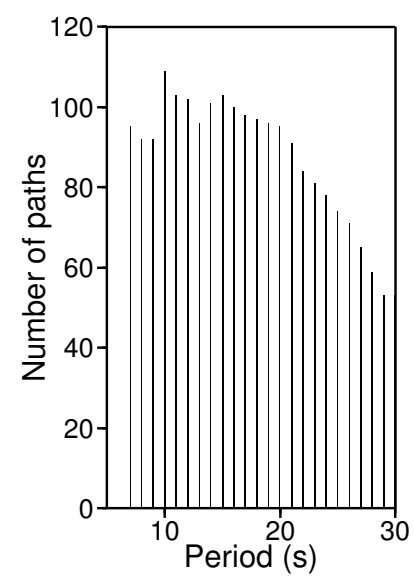

Fig. 2 Number of paths used for group velocity tomography at each period value.

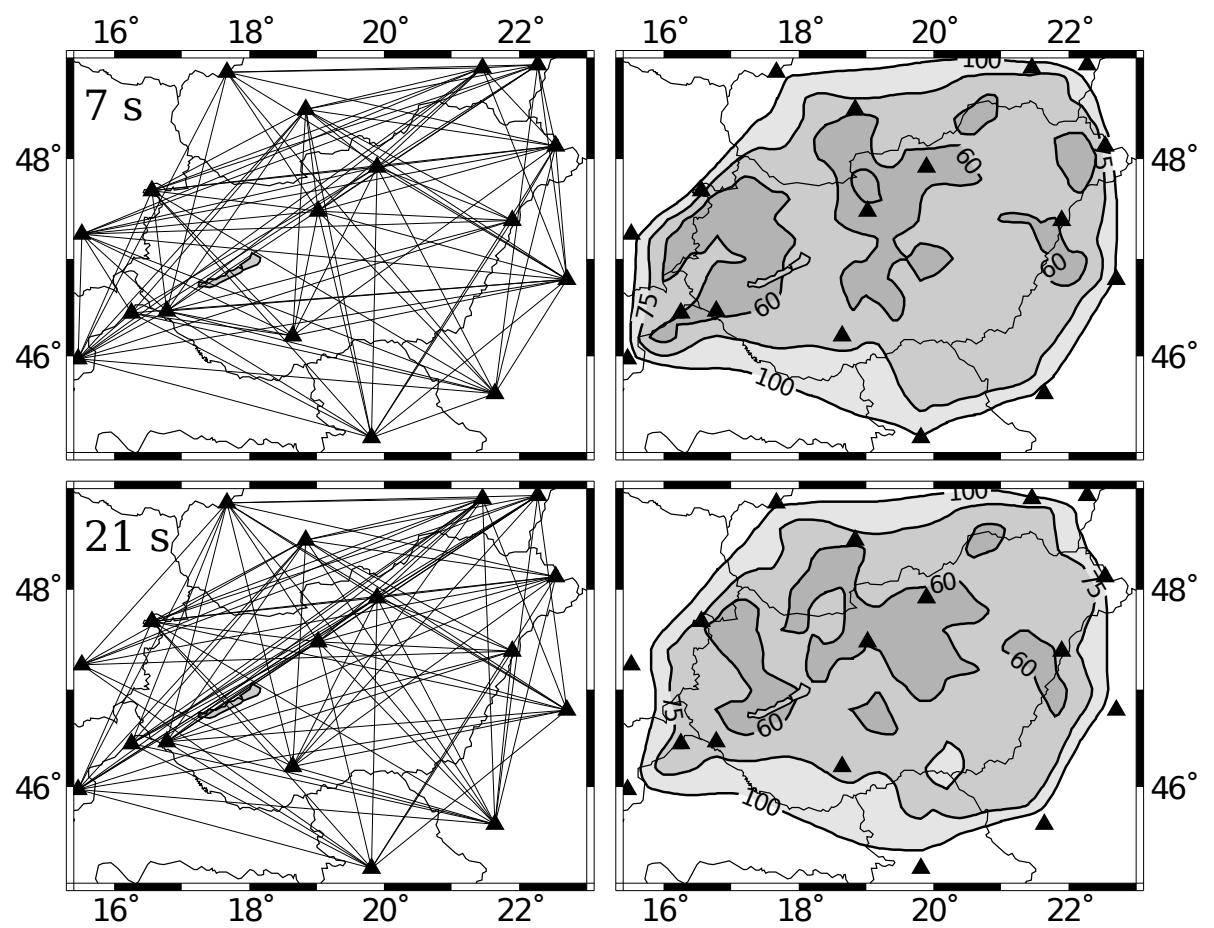

Fig. 3 Paths used for tomography at $7 \mathrm{~s}$ and $21 \mathrm{~s}$ period (left). Resolution approximated as the average of half-axes of the error ellipses (right). Gray shades correspond to the areas of at least 100, 75 and $60 \mathrm{~km}$ resolution. 
Group velocity tomography for each period was carried out using the DitmarYanovskaya method (Ditmar and Yanovskaya, 1987; Yanovskaya and Ditmar, 1990). The study region extends from $15.4^{\circ} \mathrm{E}$ to $23^{\circ} \mathrm{E}$ and from $45.0^{\circ} \mathrm{N}$ to $49.0^{\circ} \mathrm{N}$ (Fig. 1). The area was divided into $0.2^{\circ}$ by $0.2^{\circ}$ grid, and plane geometry was used. Damping parameter was set to $\alpha=0.15$ based on the trade-off curve between model roughness and data misfit.

\section{Results and discussion}

We will discuss group velocity maps at six selected periods: 7, 14, 18, 21, 25 and 28 s (Fig. 4).

The resolution is given at each grid point as the average of the half-axes of the error ellipses (see Ditmar and Yanovskaya (1987) for details). The best resolution of $60 \mathrm{~km}$ can be seen in the central part of the Pannonian basin (Fig. 3), where path density is highest, whereas resolution is only $100 \mathrm{~km}$ at the perimeter of the area. As an example, the paths for which we were able to measure group velocity values at 7 and $21 \mathrm{~s}$ periods and the corresponding resolution are shown in Fig. 3.

Seven of the stations are aligned in southwest-northeast direction, almost parallel to the path connecting the stations CRES and KOLS (Fig. 1). The dispersion curves measured on the CCFs belonging to these paths are ideal for comparison purposes, however this is an unfavourable geometry for tomography.

As a rough estimate, we can say that at a given period, the Rayleigh wave group velocity depends on the average shear wave velocity over a depth range of approximately a half wavelength (He et al, 2005; Li et al, 2012). In general, the longer the period, the deeper the surfave wave energy penetrates. The so called sensitivity kernel shows how the $\mathrm{S}$ wave velocity at a given depth affects the group velocity value at a certain period. It can be calculated from the inversion of dispersion curves as the $\frac{\partial u}{\partial \beta}$ derivatives, where $u$ is the group velocity and $\beta$ is the shear wave velocity. To estimate a representative depth range for group velocity periods, a dispersion curve was constructed using the average velocities at each period (see the lower left corners of Figs. 4a-f). The resulting dispersion curve was inverted to compute the sensitivity kernel (Fig. 5). It can be seen, that the propagation of surface waves with period of $7 \mathrm{~s}$ is strongly affected by the upper crustal structure with the maximum sensitivity at $5 \mathrm{~km}$ depth. Group velocity map at $18 \mathrm{~s}$ period reflects the sensitivity to deeper structures, mainly the lower crust at 10-20 km depth with maximum sensitivity at $12 \mathrm{~km}$, while the map at $28 \mathrm{~s}$ is affected by the $12-32 \mathrm{~km}$ depth range, i.e. the lower crust and uppermost mantle.

The velocity variations at $7 \mathrm{~s}$ period (Fig. 4a) are very consistent with surface geology units, having low velocity regions in areas with thick sediments, such as the Great and Little Hungarian Plains, and high-velocity anomalies under the mountains, such as the Western Carpathians, the North Hungarian Mountains and the Eastern Alps. The average group velocity is $2.43 \mathrm{~km} / \mathrm{s}$ for the area within the $100 \mathrm{~km}$ resolution curve. The minimum group velocity is $2.1 \mathrm{~km} / \mathrm{s}$, while the maximum is $2.9 \mathrm{~km} / \mathrm{s}$. Velocity distribution at this period clearly reflects the upper crustal structures.

It must be noted that the results of Yang et al (2007), who computed group velocity maps from ambient noise tomography across Europe on a $1^{\circ}$ by $1^{\circ}$ grid 

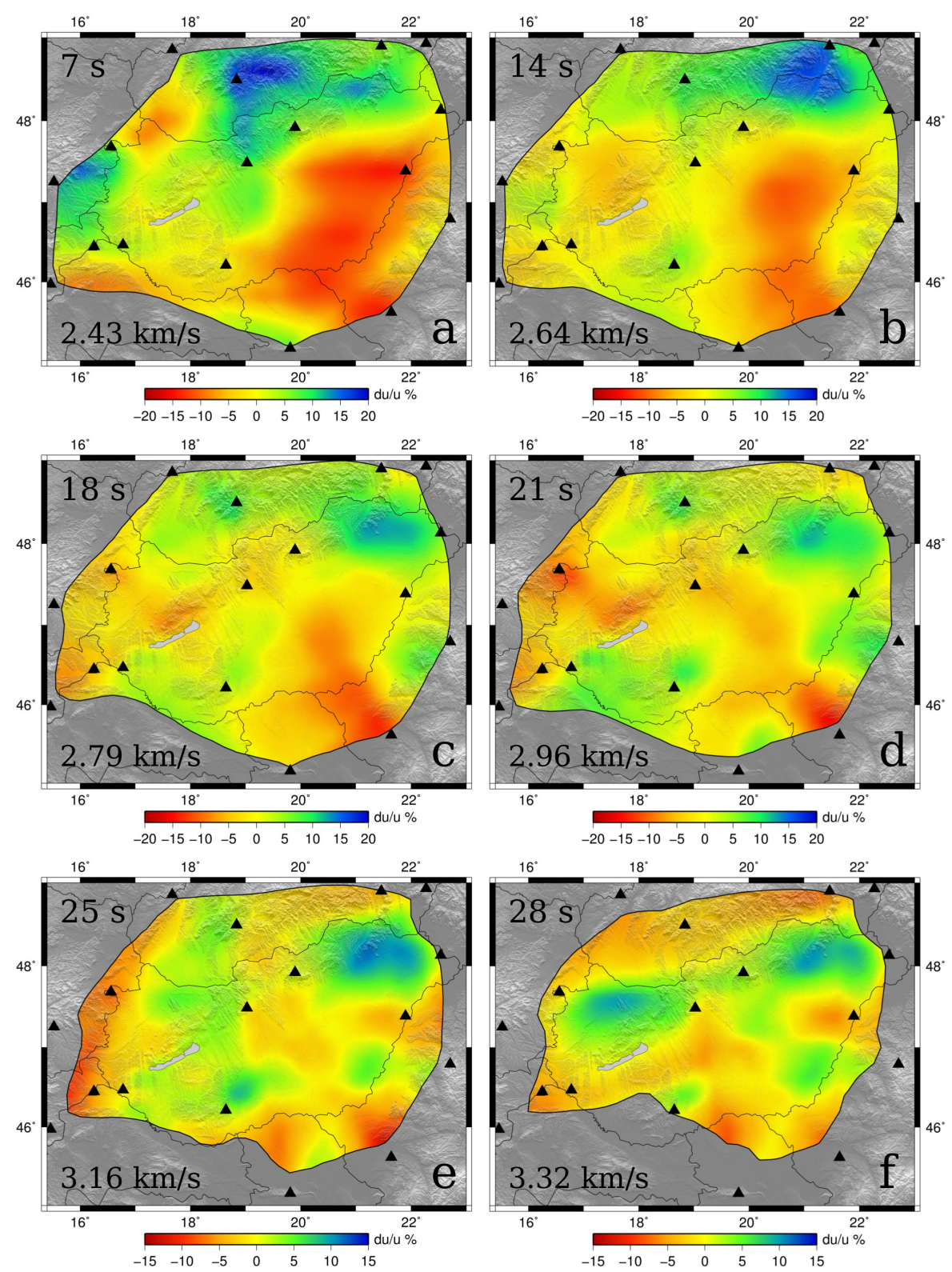

Fig. 4 Estimated Rayleigh wave group velocity maps at different periods (upper left corner). Maps are presented as a perturbation from the average velocities (lower left corner) in per cent. Areas with resolution worse than $100 \mathrm{~km}$ are clipped to gray. Note, that subfigures (e) and (f) have different velocity scales than the other ones. 


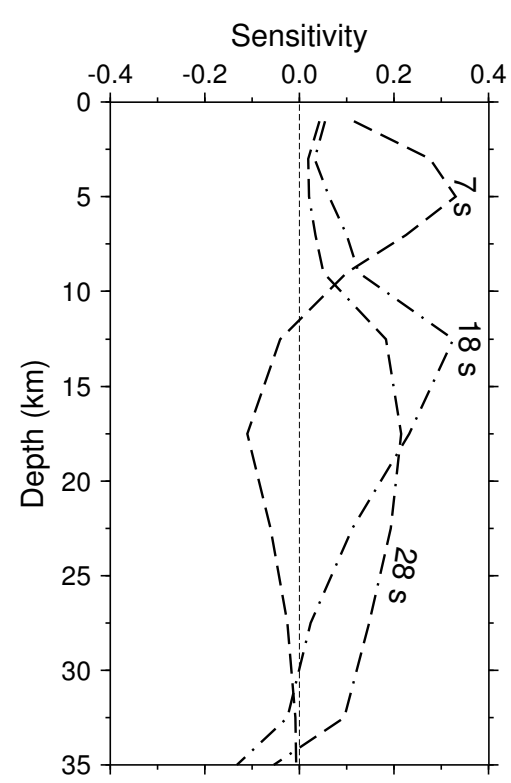

Fig. 5 Sensitivity kernels for 7 s, 18 s and 28 s period Rayleigh waves.

also showed the presence of a low velocity anomaly beneath the Great Hungarian Plain at $10 \mathrm{~s}$ period.

Group velocities at $14 \mathrm{~s}$ are shown in Fig. 4b. The low velocity anomaly under the Great Hungarian Plain changes little in shape, however its amplitude is decreasing. This is also true for the high velocity anomaly under the Eastern Alps. Prominent feature is the Western Carpathians, which is imaged as high velocity anomaly in both the 7 and $14 \mathrm{~s}$ maps, however the maximum of the anomaly is shifted to the east.

Sensitivity of $18 \mathrm{~s}$ period Rayleigh waves is highest around $12 \mathrm{~km}$ depth, however it is influenced by the $10-20 \mathrm{~km}$ depth range (Fig. 5). As the surface waves sample deeper regions, the effect of sedimentary basins decreases, however the Hungarian Great Plain is still prominent (Fig. 4c). Under the Transdanubian Hills and western Hungary negative velocity anomaly can be seen. A positive anomaly under south of Transdanubia appears. The amplitude of the negative anomaly under the Western Carpathians decreases. Highest velocities can be seen below eastern Hungary. Group velocity map of $21 \mathrm{~s}$ (Fig. 4d) shows similar pattern to the $18 \mathrm{~s}$ map, anomalies change little in shape, however, due to averaging over a large depth range, the amplitudes decrease.

Figs. 4e and $4 \mathrm{f}$ show the group velocities at 25 and 28 s period, respectively. Under the Békés basin, the Little Hungarian Plain, and eastern Hungary group velocities are above the average velocity, the highest value is $3.6 \mathrm{~km} / \mathrm{s}$; clearly associated with the thin crust in the area. Other prominent features are the low velocities mapped under the Eastern Alps and Western Carpathians (Fig. 4e), representing the mountain roots. Minimum velocities are as low as $3.0 \mathrm{~km} / \mathrm{s}$ for 28 s period. 


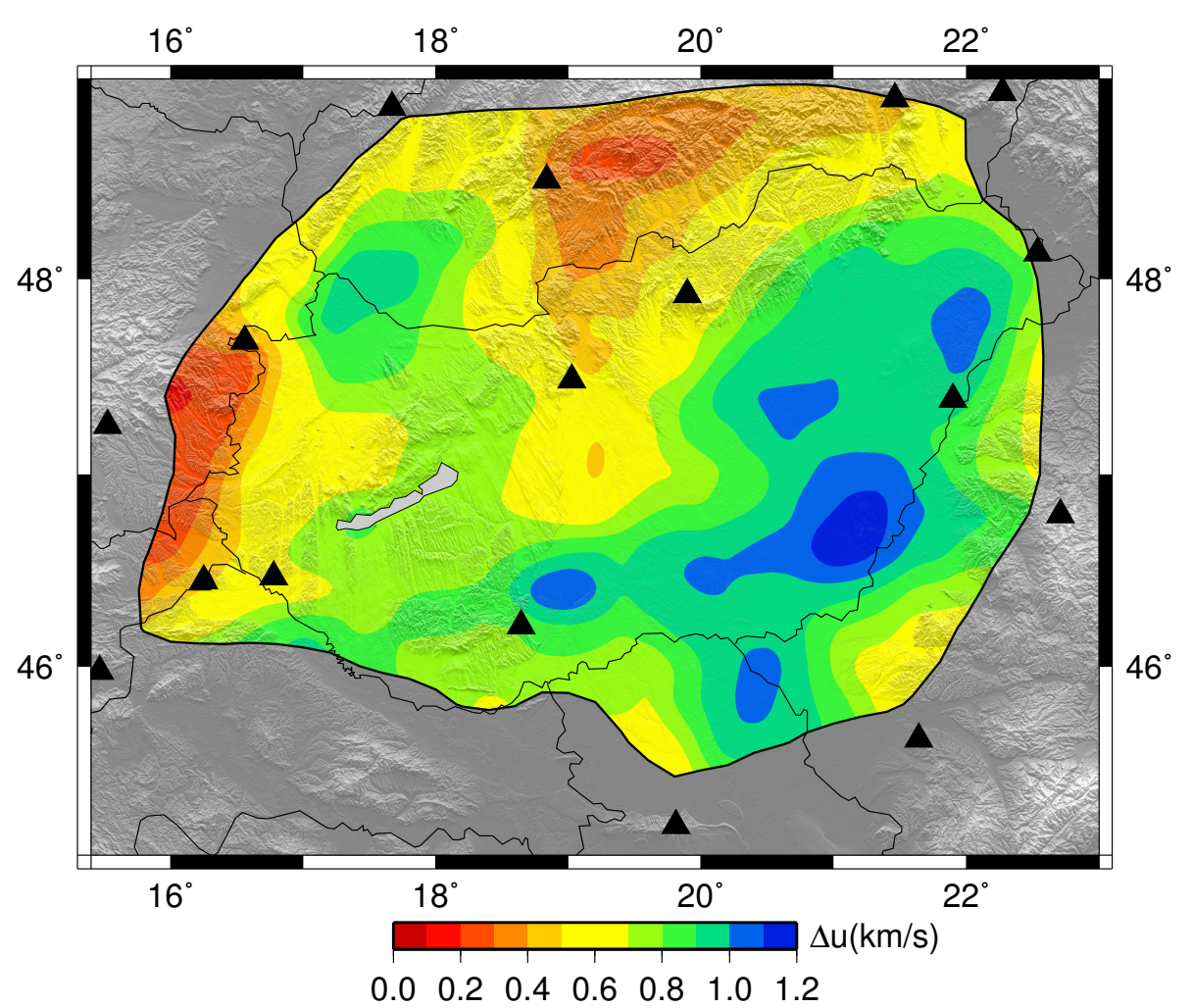

Fig. 6 Velocity differences between the group velocity maps of $7 \mathrm{~s}$ and $25 \mathrm{~s}$ period Rayleigh waves. Group velocities under the mountains (e.g. beneath Western Carpathians) change little within the studied surface wave period range, whereas velocities under the deep subbasins of the Pannonian basin increase significantly (e.g. beneath Little Hungarian Plain).

The depth of the Moho varies between 22 and $33 \mathrm{~km}$ in the studied region (Horváth et al, 2006; Grad et al, 2009). At the deep subbasins of the Pannonian basin such as the Hungarian Little Plain, the Békés basin, the Makó trench, and the Dráva basin the crust is significantly thinned, whereas under the mountains, such as the Carpathians, the Eastern Alps, and the Transdanubian Mountains it's thickened.

Where the Moho is shallower the denser material of the mantle is closer to the surface, thus longer period surface waves sample higher velocities than under the mountain ranges. This effect can be followed through Figs. $4 \mathrm{c}$ and d, where the low velocity anomalies under the thinned crust regions decrease in extent and amplitude. Longer periods represent greater depth according to the sensitivity kernel, thus group velocity distribution displayed in Figs. 4e and $\mathrm{f}$ are determined by the $\mathrm{S}$ wave structure in the lower crust and the uppermost mantle.

Velocity differences between the Rayleigh waves group velocity maps of $7 \mathrm{~s}$ and $25 \mathrm{~s}$ period are shown in Fig. 6. It's worth noticing, that absolute velocities change little under the Eastern Alps and the Western Carpathians, due to the thickened crust, whereas they increase significantly with depth under the deep sedimentary 
subbasins of the Pannonian basin; e.g. under the Békés basin it changes by approximately $1.2 \mathrm{~km} / \mathrm{s}$ (Fig. 6).

According to Posgay et al (1995) an upwelling of the lower crust and the crustmantle boundary can be inferred from various geophysical measurements beneath the Békés basin. Based on gravitational modelling a high density body is present under the basin (Szafián et al, 1997). Ádám and Bielik (1998) suggested that the area is a narrow rift zone with high-density upper-mantle material intrusion into the crust.

Our results in the Békés basin, i.e. the significant velocity increase with depth confirms the hypothesis of high density, consequently high velocity mantle intrusion.

\section{Conclusions}

Ambient seismic noise data recorded at 17 broadband seismological stations were collected and processed. Cross-correlation functions were calculated in daily segments and stacked over several months. Fundamental mode Rayleigh wave group velocities have been determined from the cross-correlation functions using a multiple filter technique. Rayleigh wave group velocity maps at periods from 7 to 28 $\mathrm{s}$ were computed using a 2D tomography method.

Group velocity maps of $7-14$ s periods correlate well with regional geology. High group velocities can be observed in the territory of the mountains, while low velocities can be seen in the sedimentary basin areas. Velocity anomalies observed at $18-28 \mathrm{~s}$ reflect the effect of the lower crust and uppermost mantle.

As expected, notable velocity increase with depth characterizes the Great and Little Hungarian Plains. The area belonging to the largest increment corresponds to the Békés basin, where an upper-mantle intrusion into the crust is assumed. Our results seem to support this hypothesis.

As the group velocity maps and the computed sensitivity kernel show that it is possible to determine the $\mathrm{S}$ wave velocity structure of the crust and uppermost mantle beneath the Pannonian basin using the ambient seismic noise data of the presently available seismological stations, the inversion of the presented group velocity maps are currently underway.

Acknowledgements The authors are indebted to Professor Tatiana B. Yanovskaya of the University of St. Petersburg, Russia for providing the tomographic inversion program and to Robert B. Herrmann for making freely available his software package called "Computer programs in seismology".

We are very grateful for allowing us to use seismic data and for the instrument parameters to the following people and institutions: Mladen Živčić at the Slovenian Environment Agency; Helmut Hausmann at the Abteilung für Geophysik - Seismologie at Zentralanstalt für Meteorologie und Geodynamik; Constantin Ionescu at the Romanian seismological observatory; Jana Pazdírková at Institute of Physics of the Earth, Masaryk University Brno and Krisztián Csicsay at Department of Seismology, Geophysical Institute, Slovak Academy of Sciences.

This study was supported by the TAMOP-4.2.2.C-11/1/KONV-2012-0015 (Earth-system) project sponsored by the EU and European Social Foundation and the Hungarian Scientific Research Fund under Grant OTKA K105399.

All figures were generated with the Generic Mapping Tools (GMT) data processing and display software package (Wessel and Smith, 1991, 1998). 


\section{References}

Ádám A, Bielik M (1998) The crustal and upper-mantle geophysical signature of narrow continental rifts in the pannonian basin. Geophysical Journal International 134(1):157-171

Babuška V, Plomerová J, Sileny J (1984) Spatial variations of P residuals and deep structure of the European lithosphere. Geophys J R Astr Soc 79:363-383

Bada G, Horváth F, Cloetingh S, Coblentz DD, Tóth T (2001) Role of topographyinduced gravitational stresses in basin inversion: The case study of the pannonian basin. Tectonics 20:343-363

Bada G, Horváth F, Dövényi P, Szafián P, Windhoffer G, Cloetingh S (2007) Present-day stress field and tectonic inversion in the pannonian basin. Global and Planetary Change 58(1):165-180

Bensen GD, Ritzwoller MH, Barmin MP, Levshin AL, Lin F, Moschetti MP, Shapiro NM, Yang Y (2007) Processing seismic ambient noise data to obtain reliable broad-band surface wave dispersion measurements. Geophysical Journal International 169(3):1239-1260, DOI 10.1111/j.1365-246X.2007.03374.x

Bensen GD, Ritzwoller MH, Shapiro NM (2008) Broadband ambient noise surface wave tomography across the United States. Journal of Geophysical Research 113:B05,306, DOI 200810.1029/2007JB005248

Boaga J, Vaccari F, Panza GF (2010) Shear wave structural models of Venice Plain, Italy, from Time Cross Correlation of seismic noise. Engineering Geology 116(3-4):189-195

Bondár I, Bus Z, Zivcic M, Costa G, Levshin A (1996) Rayleigh wave group and phase velocity measurements in the Pannonian basin. In: Special Publications of the Geological Society of Greece, No. 6, pp 73-86

Bus Z (2003) S-wave velocity structure beneath the Mátra Mountains (Hungary) inferred from teleseismic receiver functions. Acta Geodaetica et Geophysica Hungarica 38(1):93-102, DOI 10.1556/AGeod.38.2003.1.11

Bus Z (2004) A Kárpát-medence szeizmikus hullámsebesség-eloszlásának tomográfiai vizsgálata. PhD thesis, Eötvös Loránd Tudományegyetem, Budapest

Calcagnile G, Panza GF (1990) Crustal and upper mantle structure of the Mediterranean area derived from surface-wave data. Phys Earth Planet Inter 60:163-168

Campillo M, Paul A (2003) Long-Range Correlations in the Diffuse Seismic Coda. Science 299(5606):547 -549, DOI 10.1126/science.1078551

Dando BDE, Stuart GW, Houseman GA, Hegedüs E, Brückl E, Radovanović S (2011) Teleseismic tomography of the mantle in the Carpathian-Pannonian region of central Europe. Geophysical Journal International 186(1):11-31

Ditmar PG, Yanovskaya TB (1987) Generalization of Backus-Gilbert method for estimation of lateral variations of surface wave velocities. Phys Solid Earth, Izvestia Acas Sci USSR 23(6):470-477

Dziewonski A, Bloch S, Landisman M (1969) A technique for the analysis of transient seismic signals. Bulletin of the Seismological Society of America 59:427 $-444$

Fan G, Wallace TC (1998) Tomographic imaging of deep velocity structure beneath the eastern and Southern Carpathians, Romania: Implications for continental collision. J Geophys Res 103(B2):2705-2723

Gaite B, Iglesias A, Villaseñor A, Herraiz M, Pacheco JF (2012) Crustal structure of Mexico and surrounding regions from seismic ambient noise tomogra- 
phy. Geophysical Journal International 188(3):1413-1424, DOI 10.1111/j.1365246X.2011.05339.x

Gráczer Z, Wéber Z (2012) One-dimensional P-wave velocity model for the territory of Hungary from local earthquake data. Acta Geodaetica et Geophysica Hungarica 47(3):344-357

Grad M, Guterch A, Keller G, Janik T, Hegedüs E, Vozár J, Ślaczka A, Tiira T, Yliniemi J (2006) Lithospheric structure beneath trans-Carpathian transect from Precambrian platform to Pannonian basin: CELEBRATION 2000 seismic profile CEL05. Journal of Geophysical Research 111:B03,301

Grad M, Tiira T, Group EW (2009) The Moho depth map of the European Plate. Geophysical Journal International 176(1):279-292

Granet M, Trampert J (1989) Large-scale P-velocity structures in the EuroMediterranean area. Geophys J Int 99:583-594

Guterch A, Grad M, Keller GR, Posgay K, Vozár J, Spicak A, Brueckl E, Hajnal Z, Thybo H, Oguz S (2000) CELEBRATION 2000: Huge seismic experiment in Central Europe. Geologica Carpathica 51:413-414

Guterch A, Grad M, Špičák A, Brückl E, Hegedüs E, Keller GR, Thybo H (2003) Special Contribution: An Overview of Recent Seismic Refraction Experiments in Central Europe. Studia geophysica et geodaetica 47(3):651-657

He Z, Ye T, Su W (2005) 3-D Velocity Structure of the Middle and Upper Crust in the Yunnan Region, China. Pure and Applied Geophysics 162(12):2355-2368

Hearn TM (1999) Uppermost mantle velocities and anisotropy beneath Europe. Journal of Geophysical Research 104(B7):15,123-15,139, DOI 199910.1029/1998JB900088

Herrmann R (1973) Some aspects of band-pass filtering of surface waves. Bulletin of the Seismological Society of America 63(2):663

Herrmann RB, Ammon CJ (2002) Computer Programs in Seismology: Surface Waves, Receiver Functions and Crustal Structure. Saint Louis University, Missouri

Hetényi G, Stuart GW, Houseman GA, Horváth F, Hegedűs E, Brückl E (2009) Anomalously deep mantle transition zone below Central Europe: Evidence of lithospheric instability. Geophysical Research Letters 36(21):L21,307

Hetényi Gy, Bus Z (2007) Shear wave velocity and crustal thickness in the Pannonian Basin from receiver function inversions at four permanent stations in Hungary. Journal of Seismology 11:405-414, DOI 10.1007/s10950-007-9060-4

Horváth F (1993) Towards a mechanical model for the formation of the pannonian basin. Tectonophysics 226(1):333-357

Horváth F (1995) Phases of compression during the evolution of the pannonian basin and its bearing on hydrocarbon exploration. Marine and Petroleum Geology 12(8):837-844

Horváth F (2007) A pannon-medence geodinamikája - eszmetörténeti tanulmány és geofizikai szintézis. PhD thesis, Eötvös Loránd Tudományegyetem, Budapest

Horváth F, Cloetingh S (1996) Stress-induced late-stage subsidence anomalies in the Pannonian basin. Tectonophysics 266(1):287-300

Horváth F, Bada G, Windhoffer G, Csontos L, Dombrádi E, Dövényi P, Fodor L, Grenerczy Gy, Síkhegyi F, Szafián P, Székely B, Timár G, Tóth L, Tóth T (2006) Atlas of the present-day geodynamics of the Pannonian basin: Euroconform maps with explanatory text. Magyar Geofizika 47:133-137 
Hovland J, Gubbins D, Husebye ES (1981) Upper mantle heterogeneities beneath central Europe. Geophys J R Astr Soc 66:261-284

Kim S, Nyblade AA, Rhie J, Baag CE, Kang TS (2012) Crustal S-wave velocity structure of the Main Ethiopian Rift from ambient noise tomography. Geophysical Journal International 191(2):865-878, DOI 10.1111/j.1365246X.2012.05664.x

Larose E (2004) Imaging from one-bit correlations of wideband diffuse wave fields. Journal of Applied Physics 95(12):8393, DOI 10.1063/1.1739529

Larose E, Derode A, Clorennec D, Margerin L, Campillo M (2005) Passive retrieval of Rayleigh waves in disordered elastic media. Physical Review E 72(4):046,607, DOI 10.1103/PhysRevE.72.046607

Lenkey L (1999) Geothermics of the Pannonian basin and its bearing on the tectonics of basin evolution. PhD thesis, Vrije Universiteit, Amsterdam, The Netherlands.

Lenkey L, Dövényi P, Horváth F, Cloetingh S (2002) Geothermics of the Pannonian basin and its bearing on the neotectonics. Neotectonics and surface processes: the Pannonian basin and Alpine/Carpathian system 3:29-40

Li H, Li S, Song XD, Gong M, Li X, Jia J (2012) Crustal and uppermost mantle velocity structure beneath northwestern China from seismic ambient noise tomography. Geophysical Journal International

Lobkis OI, Weaver RL (2001) On the emergence of the Green's function in the correlations of a diffuse field. The Journal of the Acoustical Society of America 110:3011, DOI 10.1121/1.1417528

Mele G, Rovelli A, Seber D, Hearn TM, Barazangi M (1998) Compressional velocity structure and anisotropy in the uppermost mantle beneath Italy and surrounding regions. Journal of Geophysical Research 103:12,529-12,544

Mónus P (1995) Travel times curves and crustal velocity model for the Pannonian basin. MTA GGKI Technical Report

Piromallo C, Morelli A (2003) P wave tomography of the mantle under the AlpineMediterranean area. J Geophys Res 108(B2):ESE 1 - ESE 23

Posgay K, Albu I, Ráner G, Varga G (1986) Characteristics of the reflecting layers in the Earth's crust and upper mantle in Hungary. In: Reflection Seismology: a Global Perspective, AGU Geodyn. Ser., vol 13, pp 55-65

Posgay K, Bodoky T, Hegedüs E, Kovácsvölgyi S, Lenkey L, Szafián P, Takács E, Timár Z, Varga G (1995) Asthenospheric structure beneath a Neogene basin in southeast Hungary. Tectonophysics 252:467-484

Ratschbacher L, Merle O, Davy P, Cobbold P (1991) Lateral extrusion in the eastern alps, part 1: boundary conditions and experiments scaled for gravity. Tectonics 10(2):245-256

Royden L, Horváth F (1988) The pannonian basin: A study in basin evolution. memoir, vol. 45. American Association of Petroleum Geologists, Tulsa, Oklahoma pp $27-48$

Royden LH, Horváth F, Burchfiel B (1982) Transform faulting, extension, and subduction in the carpathian pannonian region. Geological Society of America Bulletin 93(8):717-725

Sabra KG, Gerstoft P, Fehler MC, Gerstoft P, Roux P, Kuperman WA, Kuperman WA, Fehler MC (2005) Extracting time-domain Green's function estimates from ambient seismic noise. Geophysical Research Letters 32:L03,310 
Shapiro NM, Campillo M (2004) Emergence of broadband Rayleigh waves from correlations of the ambient seismic noise. Geophysical Research Letters 31:5

Shapiro NM, Campillo M, Stehly L, Ritzwoller MH (2005) High-Resolution Surface-Wave tomography from ambient seismic noise. Science 307(5715):1615 -1618, DOI 10.1126/science.1108339

Spakman W, van der Lee S, van der Hilst R (1993) Travel-time tomography of the European-Mediterranean mantle down to $1400 \mathrm{~km}$. Phys Earth Planet Inter 79:3-74

Szafián P, Horváth F, Cloetingh S (1997) Gravity constraints on the crustal structure and slab evolution along a transcarpathian transect. Tectonophysics 272(2):233-247

Verbeke J, Boschi L, Stehly L, Kissling E, Michelini A (2012) High-resolution Rayleigh-wave velocity maps of central Europe from a dense ambient-noise data set. Geophysical Journal International 188(3):1173-1187, DOI 10.1111/j.1365246X.2011.05308.x

Villaseñor A, Ritzwoller M, Levshin A, Barmin M, Engdahl E, Spakman W, Trampert J (2001) Shear velocity structure of central Eurasia from inversion of surface wave velocities. Physics of the Earth and Planetary Interiors 123(2-4):169-184

Villaseñor A, Yang Y, Ritzwoller MH, Gallart J (2007) Ambient noise surface wave tomography of the Iberian Peninsula: Implications for shallow seismic structure. Geophysical Research Letters 34:11,304

Weaver RL, Lobkis OI (2001) Ultrasonics without a Source: Thermal Fluctuation Correlations at MHz Frequencies. Physical Review Letters 87(13):134,301

Wessel P, Smith WH (1998) New, improved version of Generic Mapping Tools released. Eos Transactions 79:579-579

Wessel P, Smith WHF (1991) Free software helps map and display data. EOS Transactions 72:441-446

Wéber Z (2002) Imaging Pn velocities beneath the Pannonian basin. Physics of the Earth and Planetary Interiors 129(3-4):283-300, DOI 10.1016/S00319201(01)00299-0

Yang Y, Ritzwoller MH, Levshin AL, Shapiro NM (2007) Ambient noise Rayleigh wave tomography across Europe. Geophysical Journal International 168(1):259274, DOI 10.1111/j.1365-246X.2006.03203.x

Yanovskaya TB, Ditmar PG (1990) Smoothness criteria in surface wave tomography. Geophysical Journal International, Geophysical Journal International 102(1):63-72

Yanovskaya TB, Kozhevnikov VM (2003) 3D S-wave velocity pattern in the upper mantle beneath the continent of Asia from Rayleigh wave data. Physics of the Earth and Planetary Interiors 138(3-4):263-278

Yao H, Van Der Hilst RD, De Hoop MV (2006) Surface wave array tomography in SE Tibet from ambient seismic noise and two station analysis-I. Phase velocity maps. Geophysical Journal International 166(2):732-744 


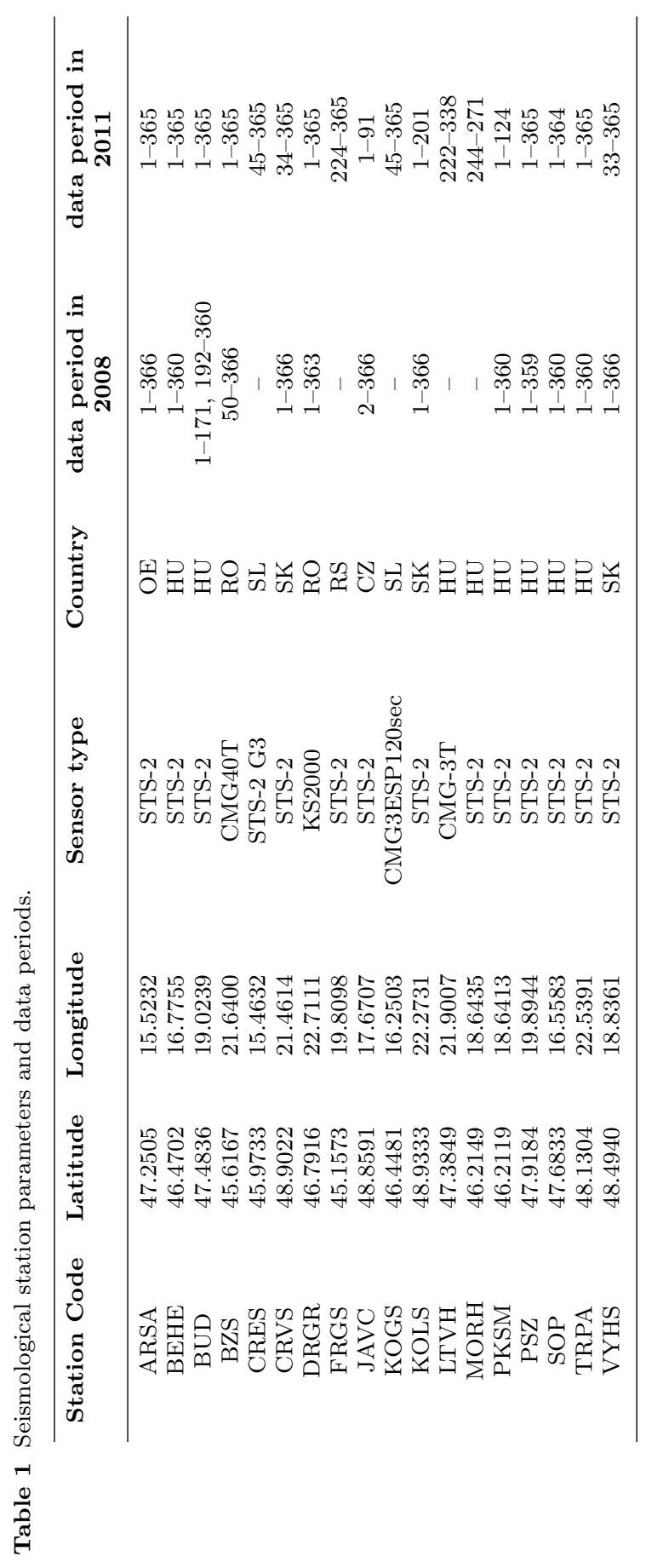

